\title{
Новые местонахождения охраняемых растений в Кемеровской области
} New localities of protected plants in the Northern part of the Kemerovo region

\author{
Романова Н. Г., Степанюк Г. Я., Филиппова А. В., Тарасова И. В. \\ Romanova N. G., Stepanjuk G. Ya., Filippova A. V., Tarasova I. V. \\ Кемеровский государственный университет, г. Кемерово, Россия.E-mail: chatn@yandex.ru \\ Kemerovo state university, Kemerovo, Russia
}

\begin{abstract}
Peферат. Приводятся сведения о новых местах произрастания 21 охраняемого вида растений, обнаруженных в Кемеровской области в 2017-2018 гг. Выявлено 59 неизвестных местонахождений в 9 административных районах. 13 видов ранее не отмечались в 6 районах. Для 15 видов уточнено распространение в административных районах, перечисленных в региональной Красной книге. Полученные данные будут использованы для уточнения статуса охраняемых видов растений в следующем издании Красной книги Кемеровской области.
\end{abstract}

Ключевые слова. Кемеровская область, Красная книга, новые местонахождения, охрана растений, распространение растений.

Summary. The article provides information on new localities for 21 protected species of plants found in the Kemerovo region in 2017-2018. 59 unknown location in 9 districts have been found. 13 species were not previously observed in 6 districts. For 15 species distribution in administrative areas listed in the regional Red book is specified. The obtained data will be used to clarify the status of protected plant species in the next edition of the Kemerovo region Red book.

Key words. Kemerovo region, new localities, plant distribution, plant protection, Red book.

В Кемеровской области произрастает порядка 1800 видов высших сосудистых растений (Шереметова, Буко, 2010; Ковригина и др., 2017а). Из них 22 занесены в федеральную, 128 - в региональные Красные книги (Красная книга ..., 2008, 2012).

Для определения природоохранного статуса и мероприятий по сохранению популяций редких видов необходимо постоянно уточнять их географическое распространение (Стратегия сохранения редких ..., 2003) путем проработки ботанических коллекций и проведения полевых исследований. Так, в процессе каталогизации Гербария Кемеровского государственного университета (КЕМ) были выявлены находки охраняемых растений, не получивших отражения в последнем издании Красной книги Кемеровской области (Ковригина и др., 2017в). В рамках мероприятий по ведению Красной книги сотрудниками Кемеровского государственного университета публиковались данные о новых местонахождениях редких видов растений и грибов на территории области (Ковригина и др., 2017б).

В данной работе приводятся сведения о новых местонахождениях редких видов сосудистых растений, обнаруженных в Кемеровской области в 2017-2018 гг. Были обследованы Ижморский, Крапивинский, Мариинский, Промышленновский, Тисульский, Юргинский, Яйский, Яшкинский административные районы.

Новые популяции редких видов: Gypsophila patrinii Ser., Nuphar pumila (Timm) DC., Nymphaea tetragona Georgi, Neottia nidus-avis (L.) Rich., Listera ovata (L.) R. Br., Ephedra monosperma C. A. Mey., Ophioglossum vulgatum L. обнаружены в районах, где они ранее не отмечались.

Gypsophila patrinii: «Тисульский р-н, окр. с. Тамбар, левый коренной берег р. Дудет, в нижней части каменистого склона южной экспозиции, каменистая разнотравно-злаковая, местами закустаренная степь. 3 VIII 2017. И. В. Тарасова, Н. Г. Романова, Б. Г. Андреев, Ю. В. Ельцова». «Яшкинский р-н, 
окр. с. Пача, правый коренной берег р. Томь, на скалистом обрыве, 20 VI 2018, А. В. Филиппова, И. В. Тарасова».

Nuphar pumila: «Мариинский р-н, окр. с. Туйла, старица р. Кия, в воде, 21 VIII 2017, И. В. Тарасова, Л. Н. Ковригина, Б. Г. Андреев».

Nymphaea tetragona: «Мариинский р-н, окр. пос. Таежно-Александровка, старица р. Кия, в воде, 20 VIII 2017, В. А. Колмыкова».

Neottia nidus-avis: «Юргинский р-н, окр. д. Новороманово, лес березово-осиновый, разнотравно-осоковый, 29 VI 2018, А. В. Филиппова, И. В. Тарасова, Б. О. Монгуш».

Listera ovata: «Яшкинский р-н, окр. г. Тайга, «Долина родников», заболоченный ивово-березовый с примесью сосны сибирской, пихты, ели лес хвощево-осоковый, 5 VI 2018, А. В. Филиппова, Г. Я. Степанюк, Б. Г. Андреев».

Ephedra monosperma: «Юргинский р-н, окр. д. Большой Улус, правый коренной берег р. Каип, остепненный каменистый склон, 10 VIII 2018, И. В. Тарасова, Л. Н. Ковригина». «Яшкинский р-н, окр. с. Пача, коренной берег р. Томь, скалистый обрыв, 24 V 2018, И. В. Тарасова, А. В. Филиппова». «Яшкинский р-н, окр. ст. Тутальская, коренной берег р. Томи (Тутальские скалы), верхняя часть холма, склон южной экспозиции, щебнистая разнотравно-овсянициевая степь, 24 V 2018, И. В. Тарасова, А. В. Филиппова, Н. Г. Романова, Б. Г. Андреев».

Ophioglossum vulgatum: «Яшкинский р-н, окр. г. Тайга, «Долина родников». Заболоченный ивово-березовый с примесью сосны сибирской, пихты, ели лес хвощево-осоковый, 5 VI 2018, А. В. Филиппова, Г. Я. Степанюк, Б. Г. Андреев».

Находки показали, что некоторые редкие виды (Leontopodium ochroleucum Beauverd, Iris humilis Georgi, Ziziphora clinopodioides Lam., Erythronium sibiricum (Fisch. et C. A. Mey ) Kryl., Cypripedium guttatum Sw., Epipactis helleborine (L.) Crantz, Epipactis palustris (L.) Crantz, Orchis militaris L.) гораздо шире распространены в пределах ранее указываемых для них административных районов.

Leontopodium ochroleucum: «Тисульский р-н, окр. д. Кайчак, верхняя часть невысокого холма, остепненный луг, 5 VIII 2017, И. В. Тарасова, Н. Г. Романова, Б. Г. Андреев, Ю. В. Ельцова».

Iris humilis: «Яшкинский р-н, окр. ст. Тутальская, правый коренной берег р. Томь (Тутальские скалы), юго-западный склон, остепненный луг, местами заросший кустарником, 24 V 2018, И. В. Тарасова, А. В. Филиппова Н. Г. Романова, Б. Г. Андреев, А. В. Ханьжина».

Ziziphora clinopodioides: «Яшкинский р-он, окр. ст. Тутальская, правый коренной берег р. Томь (Тутальские скалы), нижняя часть скального обрыва, каменистые выходы, 31 VII 2018, И. В.Тарасова, Б. Г. Андреев»; «Яшкинский р-он, окр. с. Пача, скалистый обрыв на правом коренном берегу р. Томи, 20 VI 2018, А. В. Филиппова, И. В. Тарасова».

Erythronium sibiricum ранее не отмечался для западной части Яшкинского района. «Яшкинский р-н, окр. д. Ботьево, кедровый лес с примесью сосны лесной и березы повислой, 24 V 2018, И. В. Тарасова, А. В. Филиппова, Н. Г. Романова, Б. Г. Андреев». «Яйский р-н, окр. с. Яя-Борик, берёзовый лес, 15 VI 2018, Н. Г. Романова, Г. Я. Степанюк». «Яйский р-н, окр. с. Ишим, пихтовый лес на берегу р. Яя, 15 VI 2018, Н. Г. Романова, Г. Я. Степанюк». «Яйский р-н, окр. с. Ишим, берёзово-осиновый лес с примесью сосны, 16 VI 2018, Н. Г. Романова, Г. Я. Степанюк». «Яйский р-н, окр. пос. Димитровка. молодой осиновый лес, 16 VI 2018, Н. Г. Романова, Г. Я. Степанюк». «Яйский р-н, окр. пос. Мальцево и пос. Антоново, луг, зарастающий кустарником, 16 VI 18, Н. Г. Романова, Г. Я. Степанюк».

Cypripedium guttatum: «Тисульский р-он, окр. д. Третьяково, коренной берег р. Серта, разреженный, закустаренный березовый лес, 2 VI 2017, И. В. Тарасова, А. В. Филиппова».

Epipactis helleborine: «Юргинский р-н, на границе Юргинского и Кемеровского р-нов, по старой трассе Юрга-Кемерово, лес березовый разнотравно-хвощево-злаковый, 29 VI 2018, А. В. Филиппова, И. В. Тарасова, Б. О. Монгуш».

Epipactis palustris: «Кемеровский р-н, окр. г. Кемерово, самозарастающий золошлакоотвал Кемеровской ТЭЦ, молодой лес смешанный, 9 VII 2018, Н. Г. Романова, Б. О. Монгуш, Б. Г. Андреев». «Мариинский р-н, окр. с Благовещенка, березово-сосновый разнотравный лес, 17 VI 2017 г, Л. Н. Ковригина, И. В. Тарасова, Н. Г. Романова». «Тисульский р-н, окр. пгт Тисуль, побережье оз. Цимлянское, 
заболоченный березовый лес разнотравный, 5 VIII 2017, И. В. Тарасова, Н. Г. Романова, Б. Г. Андреев, Ю. В. Ельцова».

Orchis militaris: «Кемеровский р-н, окр. г. Кемерово, самозарастающий золошлакоотвал Кемеровской ТЭЦ, молодой лес березово-сосновый с примесью осины, 9 VII 2018, Н. Г. Романова, Б. О. Монгуш, Б. Г. Андреев». «Тисульский р-н, окр. пос. Утинка, обочина заболоченной лесной дороги между озерами Утиное и Змеиное, заросли молодых деревьев, 2 VI 2017, И. В. Тарасова, А. В. Филиппова».

Несколько видов (Cypripedium macranthon Sw., Dactylorhiza fuchsii (Druce) Soo, Malaxis monophyllos (L.) Sw., Neottianthe cucullata (L.) Schlecht., Stipa pennata L., Salvinia natans (L.) All.), с одной стороны, обнаружены в районах, где они ранее не отмечались, с другой - найдены в новых точках ранее указываемых для них административных районов.

Cypripedium macranthon ранее не отмечался в Ижморском районе. «Ижморский р-н, в окр. пос. Котовский, загущенные заросли молодых деревьев: березы, осины, ивы козьей осоково-разнотравные, 20 VII 2018, И. В. Тарасова, Н. Г. Романова».

Для Мариинского и Тисульского р-нов найдены новые местонахождения. «Мариинский р-н, окр. пос. Правдинка, сосново-березово-осиновый лес орляково-разнотравный, 17 VI 2017, Л. Н. Ковригина, И. В. Тарасова, Н. Г. Романова». «Тисульский р-н, окр. д. Третьяково, коренной берег р. Серта, разреженный, закустаренный березовый лес, 2 VI 2017г., И. В. Тарасова, А. В. Филиппова». «Тисульский р-н, окр. д. Утинка, берег оз. Утиное, ивовые заросли на берегу озера, 2 VI 2017, И. В. Тарасова, А. В. Филиппова».

Dactylorhiza fuchsii впервые отмечен в Мариинском, Яйском и Яшкинском районах. «Мариинский р-н, окр. с. Малый Антибес, берег р. Кия, опушка березового леса разнотравного, 16 VI 2017, Л. Н. Ковригина, И. В. Тарасова, Н. Г. Романова». «Мариинский р-н, окр. с. Благовещенка, лес березово-сосновый разнотравный, 16 VI 2017, Л. Н. Ковригина, И. В. Тарасова, Н. Г. Романова». «Мариинский р-н, окр. пос. Правдинка, сосново-березово-осиновый лес орляково-разнотравный, 16 VI 2017, Л. Н. Ковригина, И. В. Тарасова, Н. Г. Романова». «Мариинский р-н, окр. с. Красные Орлы, берег пруда на р. Сулуюл, березово-ивовый лес, потравленный выпасом скота, 16 VI 2017, Л. Н. Ковригина, И. В. Тарасова, Н. Г. Романова». «Мариинский р-н, окр. с. Тенгулы, березовый лес с примесью сосны лесной, осоковый, заболоченный, закочкаренный, расположенный по окраине низинного осокового болота, 20 VIII 2017, Л. Н. Ковригина, И. В. Тарасова, Б. Г. Андреев». «Мариинский р-н, окр. с. Таежно-Михайловка, сосновый разреженный лес, без травяного яруса, 20 VIII 2017, Л. Н. Ковригина, И. В. Тарасова, Б. Г. Андреев». «Мариинский р-н, окр. пос. Таежно-Александровка, смешанный елово-березовый лес с примесью сосны лесной, заболоченный, закочкаренный осокой дернистой, 20 VIII 2017, Л. Н. Ковригина, И. В. Тарасова, Б. Г. Андреев». «Яйский р-н, окр. с. Бекет, заросли молодых деревьев и кустарников у подножия невысоких скальных выходов известняка в 30 м. от дороги, 15 VI 2018, Н. Г. Романова, Г. Я. Степанюк». «Яйский р-н, окр. с. Ишим, сосновые посадки, 27 VII 2018, И. В. Тарасова». «Яшкинский p-н, окр. г. Тайга, «Долина родников», лес пихтовый разнотравно-снытиевый, 5 VI 2018, А. В. Филиппова, Г. Я. Степанюк, Б. Г. Андреев».

Ранее указывался для Ижморского и Тисульского районов. Новые точки: «Ижморский р-н, окр. д. Новоорловка, лес березово-еловый заболоченный, зеленомошный, 20 VII 2018, И. В. Тарасова, Н. Г., Романова». «Тисульский р-н, окр. с. Утинка, побережье оз. Утиное, прибрежные заросли ивняка, разнотравные, 2 VI 2017, И. В. Тарасова, А. В. Филиппова». «Тисульский р-н, окр. с. Утинка, дорога к оз. Змеиному, обочина лесной дороги в заболоченном осиново-березовом лесу, 2 VI 2017, И. В. Тарасова, А. В. Филиппова».

Malaxis monophyllos впервые обнаружен в Ижморском, Мариинском и Яшкинском районах. «Ижморский р-н, окр. д. Красная тайга, березово-сосновый лес, 11 VII 2018, Н. Г. Романова, Б. Г. Андреев». «Ижморский р-н, окр. д. Глухаринка, пихтовый лес с примесью ели зеленомошный, 11 VII 2018, Н. Г.Романова, Б. Г. Андреев». «Мариинский р-н, окр. пос. Таежно-Александровка, пихтово-березово-сосновый лес низкотравный, 20 VIII 2017, И. В. Тарасова, Л. Н. Ковригина, Б. Г. Андреев». 
«Яшкинский р-н, окр. г. Тайга, «Долина родников», лес пихтовый разнотравно-снытиевый, 5 VI 2018 г. А. В. Филиппова, Г. Я. Степанюк, Б. Г. Андреев».

Новое местонахождение обнаружено в Тисульском районе: «Тисульский р-н, окр. пос. Тисуль, побережье оз. Цимлянского, заболоченный березовый лес разнотравный, 5 VIII 2017, И. В.Тарасова, Н. Г. Романова, Б. Г. Андреев, Ю. В. Ельцова».

Neottianthe cucullata впервые найден в Ижморском и Яйском районах. «Ижморский р-н, окр. пгт. Ижморский, сосновые посадки (возраст около 30 лет), почти без травяного покрова, 24 VIII 2018, Г. Я. Степанюк, И. В. Тарасова». «Яйский р-н, окр. с. Яя-Борик, сосновые посадки (возраст более 40 лет), с разреженным травяным покровом, 24 VIII 2018, И. В. Тарасова, Г. Я. Степанюк».

Для Промышленновского района обнаружена новая точка. «Промышленновский р-н, окрестности оз. Атанай, территория Салаирского заказника. Березово-сосновый лес разнотравно-осочковый, 9 VII 2018, И. В. Тарасова, Б. Г. Андреев».

Stipa pennata впервые встретился в Тисульском и Юргинском районах. «Тисульский р-н, окр. с. Тамбар, левый коренной берег р. Дудет, в нижней части каменистого склона южной экспозиции, каменистая разнотравно-злаковая, местами закустаренная степь. 3 VIII 2017, И. В. Тарасова, Н. Г. Романова, Б. Г. Андреев, Ю. В. Ельцова». «Юргинский р-н, долина р. Кунгурка (левого притока р. Томь), склон южной экспозиции, разнотравно-злаковый суходольный луг с каменистыми выходами, 29 VI 2018, А. В. Филиппова, И. В. Тарасова». «Юргинский р-н, долина р. Кунгурка (левого притока р. Томь), южный остепненный склон холма, ковыльная степь, 30 VIII 2018, И. В. Тарасова, А. В.Филиппова».

В Яшкинском районе зафиксирована новая точка. «Яшкинский р-н, окр. с. Пача, склон коренного берега р. Томи, остепненный злаковый луг, 20 VI 2018, И. В. Тарасова, А. В. Филиппова».

Salvinia natans впервые обнаружен в Кемеровском районе, это самая северная точка его встречаемости в области. «Кемеровский р-н, правый берег р. Томь, окр. пос. Городок, пойменное озеро Черное, в воде, 10 VII 2017, А. В. Филиппова».

Ранее вид отмечался в Крапивинском районе. Новое местонахождение: «Крапивинский р-н, окр. пос. Зеленогорский, гидроотвал, в воде, 10 VI 2017, Л. Н. Ковригина; окр. с. Банное, озеро Бобровое, в воде, 20 VI 2017, А. В. Филиппова, И. В. Тарасова, Б. Г. Андреев».

Таким образом, в 2017-2018 гг. для 21 охраняемого вида растений выявлено 59 неизвестных местонахождений в 9 административных районах Кемеровской области. 13 видов ранее не отмечались в 6 районах. Для 15 видов уточнено распространение в административных районах, перечисленных в региональной Красной книге. Полученные данные будут использованы для уточнения статуса охраняемых видов растений в следующем издании Красной книги Кемеровской области.

\section{ЛИТЕРАТУРА}

Ковригина Л. Н., Иванов В. И., Романова Н. Г., Филиппова А. В., Тарасова И. В. Кадастр высших растений Кемеровской области, 2017а. - Свид. о гос. регистрации базы данных № 2017621117 от 27.09.2017

Ковригина Л. Н., Романова Н. Г., Филиппова А. В., Тарасова И. В. Новые местонахождения охраняемых растений и грибов в Кемеровской области // Экология и управление природопользованием: Сб. науч. тр. Первой всерос. науч.-практ. конф. с междунар. участием (Томск, 24-25 ноября 2016 г.). - Томск: Литературное бюро, 2017б. C. $123-124$.

Ковригина Л. Н., Филиппова А. В., Тарасова И. В., Романова Н. Г. Уточнение местонахождений охраняемых растений по материалам гербария Кемеровского государственного университета // Вестн. Кемеров. гос. ун-та. Сер.: Биол., техн. науки и науки о Земле, 2017в. - № 1. - С. 10-15.

Красная книга Кемеровской области. Редкие и находящиеся под угрозой исчезновения виды растений и грибов. - Кемерово: Азия принт, 2012. - 206 с.

Красная книга Российской Федерации (растения и грибы). - М.: Товарищество научных изданий КМК, 2008. -885 c.

Стратегия сохранения редких и находящихся под угрозой исчезновения видов животных, растений и грибов. - М., 2003. $-35 \mathrm{c}$.

Шереметова C. A., Буко T. $\boldsymbol{E}$. К вопросу о переиздании определителя растений Кемеровской области // Ботанические исследования Сибири и Казахстана: Сб науч. тр., 2010. - Вып. 16. - С. 72-75. 